\title{
Effects of salinity on the transcriptome of growing maize leaf cells point at cell-age specificity in the involvement of the antioxidative response in cell growth restriction
}

Michael Kravchik and Nirit Bernstein ${ }^{*}$

\begin{abstract}
Background: Salinity inhibits growth and development of most plants. The response to salinity is complex and varies between plant organs and stages of development. It involves challenges of ion toxicities and deficiencies as well as osmotic and oxidative stresses. The range of functions affected by the stress is reflected in elaborate changes to the transcriptome. The mechanisms involved in the developmental-stage specificity of the inhibitory responses are not fully understood. The present study took advantage of the well characterized developmental progression that exists along the maize leaf, for identification of salinity induced, developmentally-associated changes to the transcriptome. Differential subtraction screening was conducted for cells of two developmental stages: from the center of the growth zone where the expansion rate is highest, and from older cells at a more distal location of the growing zone where the expansion rate is lower and the salinity restrictive effects are more pronounced. Real-Time PCR analysis was used for validation of the expression of selected genes.
\end{abstract}

Results: The salinity-induced changes demonstrated an age-related response of the growing tissue, with elevation of salinity-damages with increased age. Growth reduction, similar to the elevation of percentage dry matter (\%DM), and $\mathrm{Na}$ and $\mathrm{Cl}$ concentrations were more pronounced in the older cells. The differential subtraction screening identified genes encoding to proteins involved in antioxidant defense, electron transfer and energy, structural proteins, transcription factors and photosynthesis proteins. Of special interest is the higher induced expression of genes involved in antioxidant protection in the young compared to older cells, which was accompanied by suppressed levels of reactive oxygen species $\left(\mathrm{H}_{2} \mathrm{O}_{2}\right.$ and $\left.\mathrm{O}_{2}^{-}\right)$. This was coupled with heightened expression in the older cells of genes that enhance cell-wall rigidity, which points at reduced potential for cell expansion.

Conclusions: The results demonstrate a cell-age specificity in the salinity response of growing cells, and point at involvement of the antioxidative response in cell growth restriction. Processes involved in reactive oxygen species (ROS) scavenging are more pronounced in the young cells, while the higher growth sensitivity of older cells is suggested to involve effects on cell-wall rigidity and lower protein protection.

Keywords: Antioxidative response, Growth, Leaf, Maize, ROS, Salinity, Salt Stress

\footnotetext{
*Correspondence: Nirit@volcani.agri.gov.il

Institute of Soil Water and Environmental Sciences, Volcani Center, POB 6,

50-250, Bet-Dagan, Israel
} 


\section{Background}

Salinity reduces growth and development of most plant species. Ion toxicity, deficiency, ion imbalance, as well as osmotic and oxidative stresses accompany salt stress and cause plant growth restriction [1-3]. Salinity affects the plant at all levels of organization: organ, tissue and cell $[4,5]$. The response to salinity is thereby complex, involving specificity at the organ and cell levels and variability with developmental stage and age $[2,6,7]$. Very little information is available concerning the mechanisms and factors involved in the interaction between the response to salinity and the developmental stage of the plant tissue, and the mechanisms involved in restriction of leaf growth and shoot development are not yet fully understood [8]. Identification of changes involved in processes of growth and development can be aided by spatial and temporal studies, focusing on growing organs, tissues, and cells at defined stages of development $[7,9,10]$.

The array of functions which are affected by salt stress on the whole plant and the cellular levels are reflected by a complexity of changes in the transcriptome and the proteome [6,11]. Differential subtraction screening of Arabidopsis seedlings allowed identification of 84 saltregulated genes, and characterization of the SOS signaling pathway that mediates ion homeostasis and contributes to salt tolerance [12]. In maize roots $11 \%$ of the genes were affected by salinity and most of the affected genes were related to transport and signal transduction pathways [13]. Differential subtraction screening and microarray analysis identified differences in the initial responses of salt-tolerant and salt-sensitive tomato cultivars and allowed isolation of transcription factors and genes involved in SOS pathway that were differently affected by salinity and consequently can affect plant salt tolerance [14]. Additionally, Qing et al. [15] identified differences in $\mathrm{NaCl}$ effect on the transcriptome of leaves and roots at the initial phase of the stress, which demonstrated that leaves were affected by the osmotic component of the stress, while roots were influenced by water stress and $\mathrm{Na}^{+}$ accumulation. Thus, salinity affects gene expression differently at various stages of tissue development and plant organs $[6,13,15]$.

Recently, the involvement of reactive oxygen species (ROS) in the growth response of leaves to $\mathrm{NaCl}$ is gaining interest $[7,9,16]$. Salinity-stimulated increase in ROS may induce localized tissue damage [16], while reduced ROS concentrations in growing cells under salinity was suggested to restrict leaf elongation due to effects on cell-wall loosening [7,9]. Differences between the oxidative response of roots and shoots, as well as growing and mature leaf cells to salinity were identified [7] and indicated differential roles for various ROS scavenging enzymes at different cell developmental stages. Furthermore, the ameliorative effect of supplemental calcium on growth under salinity was suggested to take effect through modulating the antioxidative response as well as ROS levels [17].

The maize leaf is a good system for the study of stress effects on growth processes. Similar to most grass leaves, cell production and expansion in this leaf are restricted to a confined region at the leaf base, i.e., the growth zone $[4,18]$. This zone is characterized by a well-defined spatial gradient of cell development [4] along which salt effects are not identical, but demonstrate a characteristic response curve with cell developmental progression $[4,19]$. This system facilitates experimental sampling of tissue of unified developmental stage in the control and the salt treatments, thus preventing complications from interpretation of experimental results from tissues that differ in developmental stage [4]. The objective of the present study was to take advantage of the cell developmental progression along the leaf growing zone, to explore changes in gene expression under salinity, for identification of development-associated growth damage and tolerance mechanisms in the maize leaf. Differential subtraction screening was used to study salinity effects on the transcriptome at two developmental stages of growing leaf cells. The cDNA subtraction libraries were constructed for cells from the center of the growing tissue where the expansion rate is highest, and for older cells at a more distal portion of the growing zone, where the expansion rate is lower and the salinity restrictive effects are more pronounced. Comparison of salinity effects on the transcriptome at these two stages of cell development supported a role for processes involved in ROS scavenging and cell-wall rigidity determination in the extent of salinity response of the growing cells.

\section{Results}

\section{Effect of salinity on spatial distribution of growth along} the leaf

Salinity exerted a characteristic effect on plant development and leaf growth [4]. Shoot biomass was reduced by $43.1 \%$ under salinity and the rate of leaf elongation was reduced by $49.3 \%$ (Tables 1 and 2). The elongation zone, that is located at the leaf base, was shortened under salinity. The intensity of elongation throughout the central and distal portions of the elongation zone were reduced (Figure 1). The tissues located at the center of the growing zone,

Table 1 Effect of salinity on shoot biomass, leaf growth, and mineral contents in the leaf growing zone

\begin{tabular}{lll}
\hline Parameter & Control & Salt \\
\hline Shoot fresh biomass $(\mathrm{g})$ & $6.68 \pm 0.37$ & $3.80 \pm 0.16$ \\
Leaf elongation rate $\left(\mathrm{mm} \mathrm{h}^{-1}\right)$ & $3.75 \pm 0.05$ & $1.90 \pm 0.02$ \\
\hline
\end{tabular}

Effect of salinity on shoot biomass and leaf elongation rate $(A)$, and on Relative elemental growth rate (REGR); \% dry mater (DM), $\mathrm{Na}, \mathrm{Cl}$ and $\mathrm{Ca}$ contents of growing leaf tissue from two locations along the growing zone: $15-30 \mathrm{~mm}$ and $30-50 \mathrm{~mm}$ from the leaf base (B). Plants were grown at $1 \mathrm{mM}$ $\mathrm{NaCl}$ (control) or $80 \mathrm{mM} \mathrm{NaCl}$ (Salt). Data are means $\pm \mathrm{SE}(n=5)$. 
Table 2 Effect of salinity on shoot biomass, leaf growth, and mineral contents in the leaf growing zone

\begin{tabular}{|c|c|c|c|c|}
\hline & \multicolumn{4}{|c|}{ Distance from leaf base $(\mathrm{mm})$} \\
\hline & \multicolumn{2}{|c|}{$15-30 \mathrm{~mm}$} & \multicolumn{2}{|c|}{$30-50 \mathrm{~mm}$} \\
\hline & Control & Salt & Control & Salt \\
\hline $\operatorname{REGR}\left(h^{-1}\right)$ & $0.062 \pm 0.005$ & $0.041 \pm 0.003$ & $0.054 \pm 0.003$ & $0.018 . \pm 0.001$ \\
\hline DM (\%) & $7.35 \pm 0.19$ & $10.20 \pm 0.40$ & $6.13 \pm 0.20$ & $9.11 \pm 0.29$ \\
\hline $\mathrm{Na}\left(\mu \mathrm{mol} \mathrm{g} \mathrm{FW}^{-1}\right)$ & $0.10 \pm 0.005$ & $42.10 \pm 0.203$ & $0.15 \pm 0.005$ & $53.00 \pm 1.904$ \\
\hline $\mathrm{Cl}\left(\mu \mathrm{mol} \mathrm{g} \mathrm{FW}{ }^{-1}\right)$ & $43.0 \pm 2.0$ & $102.1 \pm 4.9$ & $42.5 \pm 2.3$ & $103.5 \pm 9.5$ \\
\hline $\mathrm{Ca}(\mu \mathrm{mol} \mathrm{g} \mathrm{FW})$ & $6.7 \pm 0.4$ & $1.5 \pm 0.1$ & $3.9 \pm 0.15 .0$ & $1.1 \pm 0.4$ \\
\hline
\end{tabular}

Effect of salinity on shoot biomass and leaf elongation rate $(A)$, and on Relative elemental growth rate (REGR); \% dry mater (DM), $\mathrm{Na}, \mathrm{Cl}$ and $\mathrm{Ca}$ contents of growing leaf tissue from two locations along the growing zone: $15-30 \mathrm{~mm}$ and $30-50 \mathrm{~mm}$ from the leaf base (B). Plants were grown at $1 \mathrm{mM}$ $\mathrm{NaCl}$ (control) or $80 \mathrm{mM} \mathrm{NaCl}$ (Salt). Data are means $\pm \mathrm{SE}(n=5)$.

15-30 $\mathrm{mm}$ from the leaf base- which include the region of highest growth intensity, and the older growing tissue located 30-50 $\mathrm{mm}$ from the leaf basewhich demonstrates reduced growth, were selected for SSH analyses. In both locations, salinity reduced elongation- by 33.9 and $66.7 \%$ in the center and distal parts of the elongation zone, respectively. The reduction was significantly higher for the distal part of the elongation zone $(\mathrm{P}<0.05)$. In accord with the higher restrictive affects of salinity on elongation of older

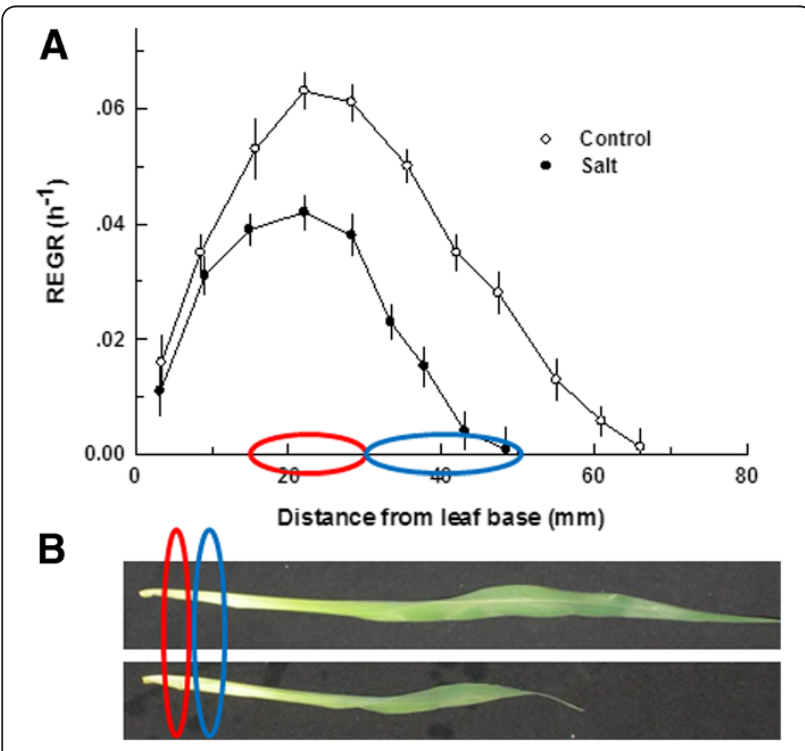

Figure 1 Effect of salinity on maize leaf growth. A. spatial distribution of REGR along the elongation zone of the leaf. The colored ovals on the $x$ axis represent the two sections of the growing tissue sampled for the SSH analysis. Data were evaluated from prick hole marking experiments of leaf 4 of maize. If not shown, error bars are smaller than the symbol size. B. A photo of leaf 4 of maize from control (top-image) and salt-stressed plants (bottom-image) at the time of sampling for the physiological analysis and SSH analysis. The plants were grown at $1 \mathrm{mM} \mathrm{NaCl}$ (control) or $80 \mathrm{mM} \mathrm{NaCl}$ (salt). compared to younger cells, the salinity-induced elevation of \% DM, and contents of $\mathrm{Na}$ were also more pronounced in the older cells. \% DM was elevated by $38.8 \%$ and $48.6 \%$ in the locations $15-30 \mathrm{~mm}$ and $30-50 \mathrm{~mm}$ from leaf base, respectively; $\mathrm{Na}$ content increased by $42.0 \mu \mathrm{mol} \mathrm{g} \mathrm{FW}^{-1}$ and $52.9 \mu \mathrm{mol} \mathrm{g} \mathrm{FW}{ }^{-1}$ in the locations $15-30 \mathrm{~mm}$ and 30-50 $\mathrm{mm}$ from leaf base, respectively (Tables 1 and 2). The elevation in \% DM and $\mathrm{Na}$ contents under salinity were significantly higher $(\mathrm{P}<0.05)$ in older compared to the younger segment. Ca content was lower in the saltstressed cells than the non-stressed ones in both sampled locations (Tables 1 and 2) and $\mathrm{Cl}$ contents increased under salinity. These salinity-induced changes, demonstrate an age- related response to salinity of the growing cells, with elevation of salinity damages with increased age. It is therefore expected, that the transcriptome should be affected differently by $\mathrm{NaCl}$ at the two studied developmental stages, reflecting changes in the resistance or response to the stress. At each location, the tissue analyzed was homogenous, i.e., contained cells of similar developmental stage- this allowed identification of developmental related changes to the transcriptome.

\section{Identification of salinity-induced changes in gene expression in the growing cells of the maize leaf by CDNA subtraction library}

To identify genes affected by salinity and possibly involved in the stress-induced growth restriction, PCR-based cDNA subtraction libraries were constructed from growing cells of two different developmental stages along the growing tissue of the maize leaf. The cDNA subtraction libraries were constructed for young cells from the center of the growing tissue, where the expansion rate is highest, and for older cells at a more distal portion of the growing zone, where the expansion rate is lower and the salinity effects are more pronounced. Forward and reverse subtractive hybridizations allowed identification of 72 differently salinity-affected genes in the growing leaf cells. Blastn and Blastp analysis based on nucleotide sequence or the corresponding amino acid sequence was performed in NCBI against Zea mays, rice or Arabidopsis. Identified sequences corresponding to genes are presented in Table 3.

The identified genes represented transcripts involved in various biological pathways, and could be divided into several functionality groups: genes encoding to proteins involved in antioxidant defense (13\%), electron transfer and energy (15\%), structural proteins (59\%), transcription factors (3\%) and photosynthesis proteins (10\%) (Figure 2; Table 3).

Genes encoding to structural proteins were represented by heat shock proteins (HSP) such as HSP70 that is known for its importance for stress tolerance, and ribosomal proteins that are known to be affected by salinity and play a structural role during the stress. Both these genes were 
Table 3 Functional classification, putative function (BLASTp (a) or BLASTn (b)) for the isolated genes GenBank Accession No. Gl Protein ID Annotation on Zea Mays Gene/Homolog ${ }^{\text {a }} \quad$ Score E Value Region

Antioxidant Defense

EU968806

BT018773

NM_001157202

EU958813

NM_001155533

EU960286

NM_001157741

NM_001111889

EU956253

\section{Structural}

NM_001156318

X68678.1

NM_001154900

EU977128.1

EU975955

NM_001174192

EU957585

NM_001153810

NM_001155943

BT017876

NM_001111466

EU952983

EU971467

U29159

EU963111

NM_001174804

EU959748

EU968344.1

NM_001156254

EU970864

EU958804

EU967930

EU952013.1

NM_001152240

BT085557

NM_001154333

NM_001176042

BT083594

EU948567

NM_001157043

NM_001155737

\begin{abstract}
Gl:195642911 ACG40924.1
GI:54653554 NP_001150213.1 Acyl-[acyl-carrier-protein] desaturasea

Gl:226492618 NP_001150674.1 Transaldolase 2

Gl:195618201 ACG30931.1

Aspartate aminotransferase

Gl:195621147 ACG32404.1 Acyl-CoA-binding protein

Gl:226499079 NP_001151213.1 Dihydroflavonol-4-reductase

Gl:162459146 NP_001105359.1 Carbonic anhydrase

Gl:195613081 ACG28371.1

Phosphoserine phosphatase
\end{abstract}

Isovaleryl-CoA dehydrogenase mRNA

3-isopropylmalate dehydratase small subunit 2

\begin{tabular}{|c|c|c|}
\hline Gl:226500875 & NP_001149790.1 & Peptidyl-prolyl isomerase/cyclophylin \\
\hline Gl:829147 & CAA48638.1 & Cyclophylin \\
\hline Gl:226497771 & NP_001148372.1 & $\begin{array}{l}\text { Zn-finger, RanBP-type, cyclophilin-related } \\
\text { protein }\end{array}$ \\
\hline Gl:195659556 & ACG49246.1 & UDP-glucuronic acid decarboxylase \\
\hline 95657210 & ACG48073.1 & DNA-3-methyladenine glycosylase I \\
\hline
\end{tabular}

G.293331322 NP 001167663.1 Tubulin alpha-3 chain

Gl:195615745 ACG29703 Retrotransposon protein

Gl:226532905 NP_001147282.1 Ca2+-binding protein (EF-Hand superfamily)

Gl:226506681 NP_001149415.1 CTD

Gl:54652657

TIC21 iron ion transmembrane transporter

Gl:162458261 NP_001104936.1 Dihydrolipoamide S-acetyltransferase

Gl:195606541 ACG25101.1

Threonine endopeptidase

Gl:195648233 ACG43585.1

Calmodulin

GI:902583 AAC49013.1

MubG1 ubiquitin gene

Gl:195626797 ACG35229.1 Esterase precursor

Gl:293334320 NP_001168275.1 Translation initiation factor 4

GI:195620071 ACG31866.1

Elongation factor $1 \mathrm{~A}$

Gl:195641987 ACG40462.1

$60 S$ ribosomal protein $\mathrm{L} 3$

Gl:226502948 NP_001149726.1 60S ribosomal protein L5-1

Gl:195647027 ACG42982.1

40 S ribosomal protein $\$ 19$

Gl:195618183 ACG30922.1

40 S ribosomal protein S4

Gl:195641159 ACG40048.1

40 S ribosomal protein S27a

Gl:195604601 ACG24131.1 30S ribosomal protein 3

Gl:226505273 NP_001145712.1 SORBIDRAFTaSb=HSP70 cognate

Gl:238009749 ACR35910.1 Heat shock protein 70 cognate

Gl:226498819 NP_001147805.1 Heat shock 70 kDa protein 4

Gl:293336702 NP_001169513.1 TIDP2694, unknown function

Gl:238005823 ACR33947.

Transmembrane 9 superfamily protein

1 precursor

Gl:195600921 Unknown

Gl:226498795 NP_001150515.1 Dirigent-like protein pDIR9

Gl:226504345 NP_001149209.1 1-aminocyclopropane-1-carboxylate oxidase ACC oxidase

$\begin{array}{llll}333 & 1 \mathrm{e}-90 & 15-30 & 2.96 \\ 401 & 3 e-111 & 15-30 & 2.60 \\ 422 & 1 \mathrm{e}-116 & 15-30 & 2.81 \\ 387 & 1 \mathrm{e}-106 & 15-30 & 3.17 \\ 654 & 0.0 & 15-30 & 2.02 \\ 710 & 0.0 & 15-30 & 2.86 \\ 545 & 2 \mathrm{e}-154 & 15-30 & 2.54 \\ 689 & 0.0 & 30-50 & 2.20 \\ 765 & 0.0 & 30-50 & 0.46\end{array}$

$366 \quad 1-100 \quad 15-30 \quad 2.06$

$\begin{array}{llll}612 & 0.0 & 15-30 & 2.10\end{array}$

$\begin{array}{llll}1090 & 0.0 & 15-30 & 2.13\end{array}$

$\begin{array}{llll}1267 & 0.0 & 15-30 & 2.11\end{array}$

$172 \quad 3 e-42 \quad 15-30 \quad 3.14$

$824 \quad 0.0 \quad 15-30 \quad 2.82$

$\begin{array}{llll}1186 & 0.0 & 15-30 & 2.09\end{array}$

$\begin{array}{llll}669 & 0.0 & 15-30 & 2.04\end{array}$

$883 \quad 0.0 \quad 15-30 \quad 2.54$

$189 \quad 2 \mathrm{e}-47 \quad 15-30 \quad 2.85$

$\begin{array}{llll}651 & 0.0 & 15-30 & 2.47\end{array}$

$278 \quad 4 \mathrm{e}-74 \quad 15-30 \quad 2.11$

$577 \quad 8 \mathrm{e}-164 \quad 15-30 \quad 2.30$

$\begin{array}{llll}1227 & 0.0 & 15-30 & 3.39\end{array}$

$\begin{array}{llll}852 & 0.0 & 15-30 & 2.29\end{array}$

$357 \quad 7$ e-98 $\quad 15-30 \quad 3.44$

$\begin{array}{llll}1426 & 0.0 & 15-30 & 2.82\end{array}$

$370 \quad 9 \mathrm{e}-102 \quad 15-30 \quad 2.85$

$\begin{array}{lll}800 \quad 0.0 & 15-30 & 2.30\end{array}$

$\begin{array}{llll}682 & 0.0 & 15-30 & 2.96\end{array}$

$436 \quad 1 \mathrm{e}-121 \quad 15-30 \quad 2.01$

$\begin{array}{llll}710 & 0.0 & 15-30 & 2.07\end{array}$

$401 \quad 3 e-111 \quad 15-30 \quad 2.33$

$\begin{array}{llll}933 & 0.0 & 15-30 & 2.08\end{array}$

$\begin{array}{llll}837 & 0.0 & 15-30 & 2.19\end{array}$

$\begin{array}{llll}972 & 0.0 & 15-30 & 2.02\end{array}$

$451 \quad 4 \mathrm{e}-126 \quad 15-30 \quad 2.91$

$429 \quad 2 \mathrm{e}-119 \quad 15-30 \quad 2.01$

$355 \quad 4 \mathrm{E}-97 \quad 30-50 \quad 10.78$

$344 \quad 7$ - $94 \quad 30-50 \quad 2.83$

$442 \quad 3 e-123 \quad 30-50 \quad 0.48$ 
Table 3 Functional classification, putative function (BLASTp (a) or BLASTn (b)) for the isolated genes (Continued)

\begin{tabular}{|c|c|c|c|c|c|c|c|}
\hline EU946392 & Gl:195598746 & NP_001142128.1 & $\begin{array}{l}\text { Hydroxyproline-rich glycoprotein } \\
\text { family protein }{ }^{a}\end{array}$ & 662 & 0.0 & $30-50$ & 2.01 \\
\hline BT064284 & Gl:223949794 & ACN28981.1 & Aspartic proteinase & 429 & $2 e-119$ & $30-50$ & 0.48 \\
\hline BT084696 & $\mathrm{Gl}: 238008027$ & ACR35049.1 & Elongation factor $\mathrm{EF}-\mathrm{Ts}^{\mathrm{a}}$ & 305 & $2 e-82$ & $30-50$ & 0.47 \\
\hline BT061533 & Gl:223944292 & ACN26230.1 & Abhydrolase6, Hydrolase & 446 & $2 e-124$ & $30-50$ & 2.01 \\
\hline NM_001111648 & Gl:162461640 & NP_001105118.1 & Proline-rich protein; CL1298_1_ov & 459 & $2 e-128$ & $30-50$ & 0.25 \\
\hline NM_001147683 & $\mathrm{Gl}: 226505411$ & NP_001141155.1 & Oligopeptidase $\mathrm{a}^{\mathrm{a}, \mathrm{Rc}}$ & 813 & 0.0 & $30-50$ & 0.28 \\
\hline EU967200 & Gl:195639699 & ACG39318.1 & $50 S$ ribosomal protein $\mathrm{L}$ & 263 & $1 e-69$ & $30-50$ & 0.46 \\
\hline BT070196 & $\mathrm{Gl}: 224036034$ & CN37093.1 & $18 \mathrm{~S}$ ribosomal RNA gene & 838 & 0.0 & $30-50$ & 0.48 \\
\hline NM_001153810 & Gl:226532905 & NP_001147282.1 & Ca2+-binding protein (EF-Hand superfamily) & 411 & $6 e-114$ & $30-50$ & 0.48 \\
\hline EU957222 & Gl:195615019 & ACG29340.1 & Transposon protein CACTA & 411 & 7e-114 & $30-50$ & 0.24 \\
\hline NM_001138563 & Gl:212722439 & NP_001132035 & $\begin{array}{l}\text { IAA15 - auxin-responsive Aux/IAA } \\
\text { family member }\end{array}$ & 571 & $4 e-162$ & $30-50$ & 0.23 \\
\hline NM_001148300 & Gl:239050004 & NP_001141772 & PGR5-LIKE $A^{a}$ & 412 & 2e-114 & $30-50$ & 0.17 \\
\hline \multicolumn{8}{|c|}{ Transcription Factors } \\
\hline BT063988 & Gl:223949202 & ACN28685.1 & $\begin{array}{l}\text { drought-responsive factor-like transcription } \\
\text { factor }^{\mathrm{a}}\end{array}$ & 636 & 0.0 & $15-30$ & 2.41 \\
\hline NM_001155696 & Gl:226532553 & NP_001149168.1 & RING finger, CHYzinc finger domain-containing & 747 & 0.0 & $15-30$ & 2.43 \\
\hline \multicolumn{8}{|l|}{ Photosynthesis } \\
\hline EU967333 & Gl:195639965 & ACG39451.1 & Chlorophyll a-b binding protein CP24 & 241 & $5 e-63$ & $15-30$ & 2.31 \\
\hline EU959735 & Gl:195620045 & ACG31853.1 & $\mathrm{CP}$ protein & 239 & $2 e-62$ & $15-30$ & 2.81 \\
\hline AY109815 & $\mathrm{Gl}: 21213680$ & & Magnesium chelatase subunit chIDa & 619 & $1 e-176$ & $15-30$ & 2.80 \\
\hline EU965631 & Gl:195636561 & ACG37749 & Ribulose bisphosphate carboxylase small chain & 455 & $3 e-127$ & $15-30$ & 2.19 \\
\hline ВT069905 & Gl:224035452 & ACN36802.1 & AAA-metalloprotease Fts $\mathrm{H}^{\mathrm{a}}$ & 920 & 0.0 & $30-50$ & 0.46 \\
\hline EU965428 & Gl:195636155 & ACG37546.1 & Triose phosphate/phosphate translocator & 1338 & 0.0 & $30-50$ & 0.46 \\
\hline NM_001111878 & Gl:162463911 & NP_001105348.1 & Oxygen-evolving enhancer protein 3-1 & 520 & $1 e-146$ & $30-50$ & 0.48 \\
\hline \multicolumn{8}{|l|}{ Energy } \\
\hline EU953063 & Gl:195606701 & ACG25181.1 & $\begin{array}{l}\text { Glyceraldehyde-3-phosphate dehydrogenase } \\
\text { (GAPDH) }\end{array}$ & 883 & 0.0 & $15-30$ & 2.01 \\
\hline BT039975 & Gl:194701791 & ACF84980.1 & Cytosolic GAPDH & 660 & 0.0 & $15-30$ & 2.54 \\
\hline NM_001155853 & Gl:226507591 & NP_001149325.1 & ATP-citrate synthase & 723 & 0.0 & $15-30$ & 2.05 \\
\hline NM_001111964 & Gl:193211363 & NP_001105434.1 & Adenine nucleotide translocator (ANT2) & 505 & $3 e-142$ & $15-30$ & 2.60 \\
\hline EU96468 & Gl:195634658 & ACG36798.1 & Fructose-bisphosphate aldolase & 161 & 2e-39 & $15-30$ & 2.15 \\
\hline EU963078 & Gl:195626731 & ACG35196.1 & Vacuolar ATP synthase subunit $G$ & 167 & $6 e-41$ & $15-30$ & 2.00 \\
\hline BT086232 & Gl:238011099 & ACR36585.1 & Vacuolar proton-inorganic pyrophosphatase & 1042 & 0.0 & $15-30$ & 2.01 \\
\hline NM_001155046 & Gl:226508897 & NP_001148518.1 & Malate dehydrogenase, glyoxysomal & 1158 & 0.0 & $15-30$ & 2.06 \\
\hline EU952363 & Gl:195605301 & NP_001169698.1 & 2-oxoglutarate dehydrogenase E1 & 326 & $3 e-88$ & $15-30$ & 2.23 \\
\hline EU955065 & Gl:195610705 & ACG27183.1 & Inorganic pyrophosphatase & 1099 & 0.0 & $30-50$ & 2.96 \\
\hline NM_001111961 & Gl:193211484 & NP_001105431.1 & Adenine nucleotide translocator (ANT1) & 278 & $4 \mathrm{e}-78$ & $30-50$ & 0.48 \\
\hline
\end{tabular}




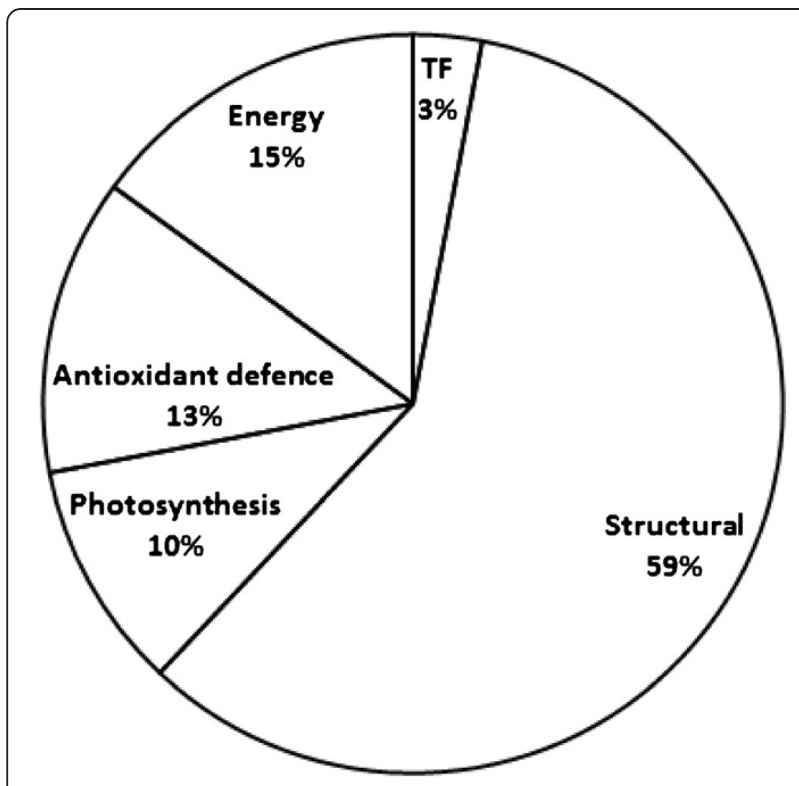

Figure 2 Division of $\mathrm{NaCl}$-affected transcripts obtained from the SSH library to functional groups. The percentages in the piechart sections represent the ratio between various groups in the SSH library. The names of groups in the figure correspond to the group-names in Table 1. TF is transcription factor.

induced in the region of maximal growth, i.e., the youngest segment sampled for the analyses, and were down-regulated in distal parts of the growth zone. The elongation factors EF1A and EF-Ts, which can both act as chaperones under the stress, were up-regulated in the cells location 15-30 $\mathrm{mm}$ from the leaf base, and down regulated at the distal $20 \mathrm{~mm}(30-50 \mathrm{~mm}$ from the leaf base). The structural gene hydroxyproline-rich glycoprotein, that can induce plant osmoprotection, was induced as well in the distal region of the growth zone $(30-50 \mathrm{~mm}$ from the leaf base).

A number of genes that can affect various processes in the cell were affected. For example dirigent protein pDIR9 and 1-aminocyclopropane-1-carboxylate oxidase (ACC oxidase), that their proteins can affect rigidity of the cell-wall were up-regulated and down-regulated, respectively by salinity at the distal part of the growth zone. Energy metabolism was affected as well: most of the genes involved in energy metabolism were induced, and isolated from the library generated from the tissue located 15-30 mm from leaf base. For example, vacuolar inorganic pyrophosphatase that its hydrolysis supplies energy that drives $\mathrm{H}^{+}$translocation into vacuoles, thereby aiding in generation of the transmembrane potential, was increased in the young tissue.

Genes involved in photosynthesis were affected differently in the two studied regions: at $15-30 \mathrm{~mm}$ from leaf base they were up-regulated by salinity, possibly representing the earlier development of the photosynthetic apparatus under salinity, while in the older cells from the location $30-50 \mathrm{~mm}$ from the leaf base they were down-regulated, probably representing $\mathrm{NaCl}$ damages to the fully photosynthetic tissue.

Intriguingly, a large share of the identified genes is associated with the plant antioxidant response and most of these genes were isolated from the $15-30 \mathrm{~mm}$ region, where growth is highest. For example, isovaleryl-CoA dehydrogenase (IVDH) that acts in the mitochondria, jasmonate-responsive (JR) genes such as 3-isopropylmalate dehydratase, and aspartate aminotransferase were upregulated by $\mathrm{NaCl}$ in the young tissue segment. But over expression of antioxidant genes was also found in more distal region of the growing zone, for example for carbonic anhydrase. In addition to the genes listed in the antioxidant group to increase at the location $15-30 \mathrm{~mm}$ from the base, numerous other genes categorized in other groups (Table 3) can have an antioxidant activity as well. For example, the oxygen-evolving enhancer from the photosynthetic group, that involves in protection against photo-damages of the photosynthetic machinery increased in the location $15-30 \mathrm{~mm}$, and so did the glyoxysomal malate dehydrogenase, that can stimulate glyoxysome activity and participate in energy generation. Glyoxysomes are a subclass of peroxisomes which play as well a role in antioxidant defense throughout fatty acid oxidation.

\section{Expression validation of differently affected genes}

Real-Time PCR analysis was used for validation of the expression of several genes related to different groups as defined in Figure 3. The expressions of the genes encoded to inorganic pyrophosphotase $(\mathrm{PPi})$, vacuolar inorganic pyrophosphotase (V-PPi), isovaleryl-CoA dehydrogenase (I-coA DH), dirigent-like protein (pDIR9) and peptidyl-prolyl isomerase (PPIase) was higher under salinity throughout the growing zone, in accord with the results obtained by the SSH. The expression level of ascorbate peroxidase (APX) (an antioxidant defense gene) that was not detected in the SSH library was found not to differ significantly between the control and salinity treatments in the Real-Time analysis as well. The expression level of ICoADH and PPIase under salinity was higher in the $15-30 \mathrm{~mm}$ segment compared to the $30-50 \mathrm{~cm}$ segment.

\section{Reactive oxygen species along the maize growth zone}

In light of the observed results, which identified 13\% of the affected genes to involve in the antioxidative response, and the importance of reactive oxygen species (ROS) for cell growth, the oxidative state of the growing leaf tissue was studied. Spatial profiles of concentrations of two ROS throughout the developmental gradient that exists along the growing leaf tissue were analyzed (Figure 4). Hydrogen peroxide $\left(\mathrm{H}_{2} \mathrm{O}_{2}\right)$ was higher at the leaf base, and at the older tissue at the distal part of the 


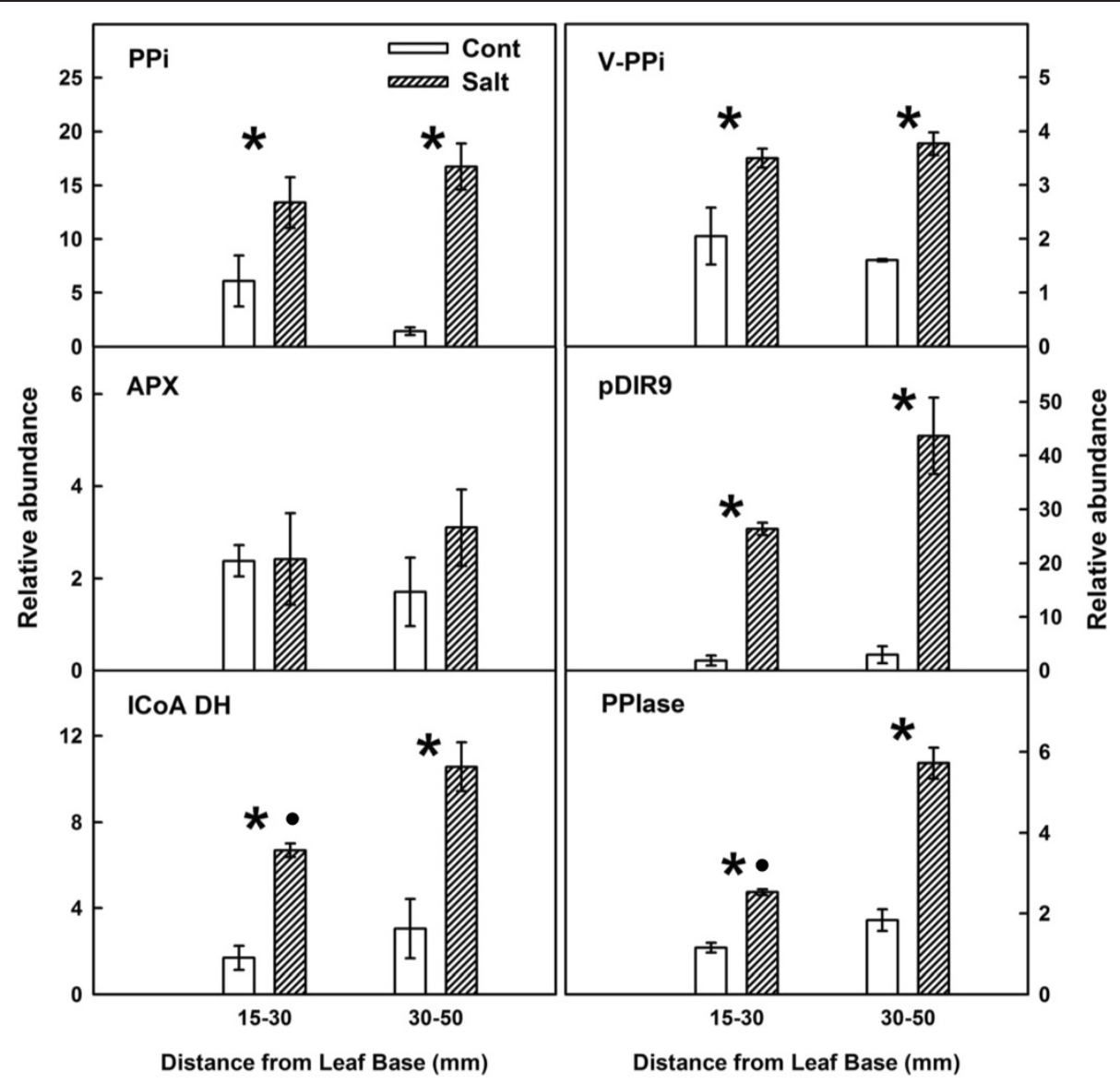

Figure 3 Salinity-induced changes to selected transcripts in growing cells of the maize leaf. Relative quantity determined by Real-Time PCR normalized to the amount of actin (Act-3, gi:21206665). White bars represent control conditions, and hatched box represent salt-stressed conditions at two locations in the elongation zone, 15-30 and 30-50 mm from the leaf base. Data are means $\pm S E(n=4-5)$. Asterisks represent significant difference between the salt stress and the control treatments for each equivalent position along the elongation zone $(P<0.05)$. Filled dot above a treatment bar represent significant difference between young $(15-30 \mathrm{~mm})$ and more mature tissue $(30-50 \mathrm{~mm})(P<0.05)$ for this treatment. The names of the evaluated genes are specified in the figures: inorganic pyrophosphate (PPi), vacuolar inorganic pyrophosphate (V-PPi), ascorbate peroxidase (APX), isovaleryl-COA dehydrogenase (ICOA DH), peptidyl-prolyl isomerase (PPlase).

growth zone, in the control compared to the salt treatment $(\mathrm{P}<0.05)$. Throughout the remaining developmental gradient, the concentration was steady and similar for the two treatments. This is unlike, superoxides $\left(\mathrm{O}_{2}^{-}\right)$ that were lower throughout the growth zone under salinity. The largest difference between the control and the salt treatment was observed at the region where the cell undergoes the highest growth rate, $15-30 \mathrm{~mm}$ from the leaf base (Figure 4). Concentrations of both superoxides and hydrogen peroxide were significantly higher at the leaf base than at the end of growth zone in both the control and the salt treatments $(\mathrm{P}<0.05)$.

\section{Discussion}

ROS was suggested to involve in cell elongation through an effect on cell-wall loosening [20-22], participation in signaling [23] and induction of degradation of macromolecules such as chlorophyll, membrane lipids, proteins and RNA under stress conditions or senescence [23,24]. Under salinity, reduction in ROS content was reported as one of the factors involved in leaf growth restriction $[7,9]$, but ROS were also reported to increase under salinity [25] and to involve in salinity-induced leaf damages [16]. Consequently, ROS is considered today to have a dual effect under salinity, on one hand they are required for normal growth of young cells, but on the other they can induce damage especially in mature tissue. In the present study (Figure 4), in accord with previous studies [7,9], salinity was observed to reduce ROS levels in the growing cells. Various ROS scavengers are active in the plant cells, such as ascorbate peroxidase (APX), superoxide dismutases (SODs), glutathione $\mathrm{S}$-transferase, and are known to involve in ROS detoxification during salt stress [2,7,23]. In the growing cells from the leaf base, APX and SOD activity was demonstrated to be significantly higher under $\mathrm{NaCl}$ [7]. The aim of the current study was to identify genes that 


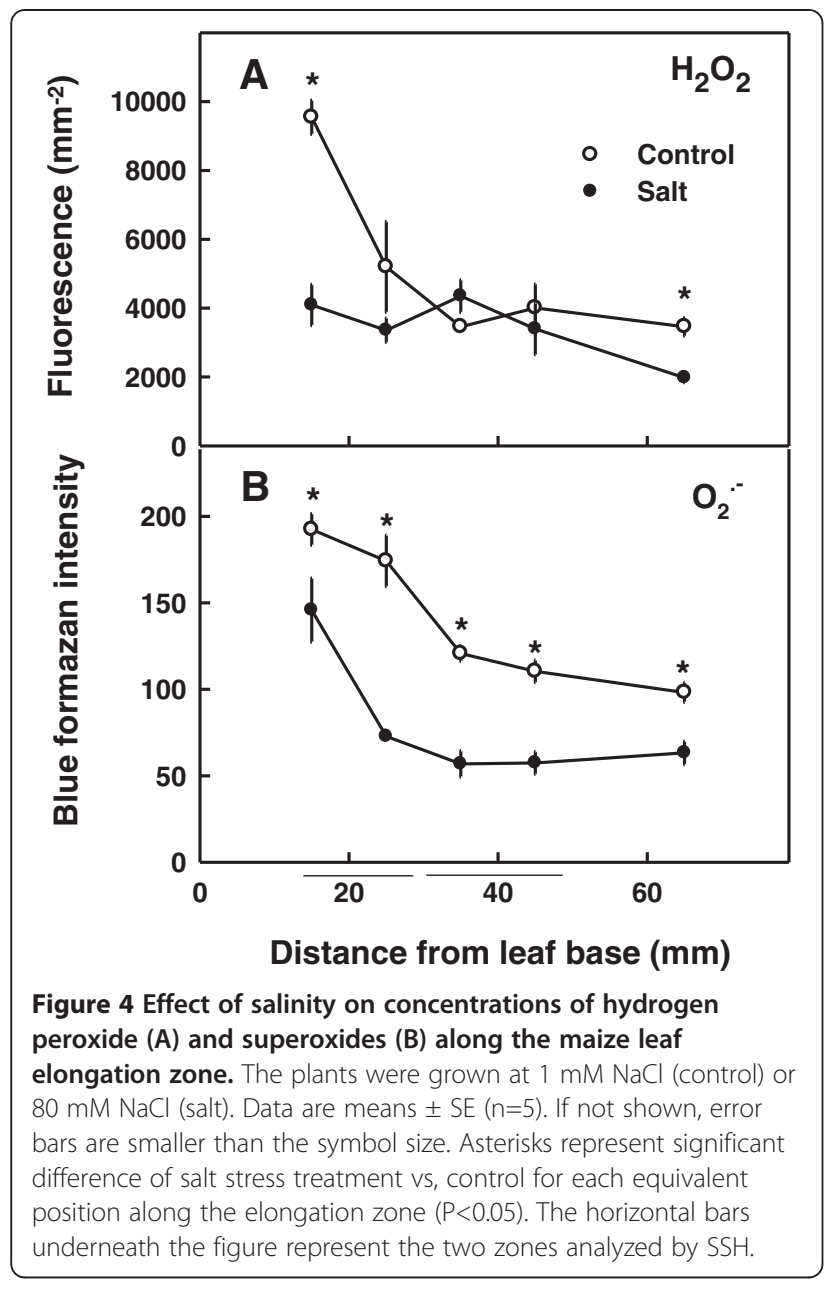

are affected by salinity specifically at defined locations along the growing zone (i.e., correlate to defined stages of tissue expansion in the leaf) and may therefore involve in leaf growth restriction at defined stages of cell development. Due to the central roles suggested for ROS in facilitating cell growth and induction of cellular damage, it is not surprising that changes in ROS contents were identified in the growing cells, and that a considerable proportion (about 13\%) of the affected genes belonged to the antioxidant group (Figure 2). Furthermore, the difference in sensitivity to salinity between cells from the two developmental stages evaluated, was reflected also in differences in antioxidant related proteins in the transcriptome.

Numerous antioxidant genes were found to be induced by salinity in the present study and most of these were isolated from the $15-30 \mathrm{~mm}$ region that was characterized by highest growth. At this region cell elongation is maximal (Figure 1), [4] and consequently there is a high demand for ROS for cell loosening [20]. The observed induction of genes involved in antioxidant defense at this early growth stage, resulted in lower ROS levels and consequently growth restriction observed previously by
Neves-Piestun and Bernstein [4] and Rodriquez et al., [9]. For example, Isovaleryl-CoA dehydrogenase (IVDH), a key enzyme in the ETF/ETFQO complex in the mitochondria that induce an alternative respiration pathway that prevents ROS production in mitochondria under various conditions [26] was up-regulated by $\mathrm{NaCl}$ in the young tissue segment. ETF/ETFQO complex was reported to be induced under oxidative stress [27] and during dark induced senescence [28], and IVDH was shown to be essential for its activity [29]. Transaldolase, a key enzyme in the pentose phosphate pathway, which is the main NADPH-producing pathway. NADPH is involved in both the thioredoxin redox cycle and the glutathione redox cycle against ROS [30,31]. Additionally, expression of jasmonate-responsive (JR) genes was found to involve in resistance to oxidative stress [32]. 3-isopropylmalate dehydratase, which catalyzes the second step in the biosynthesis of leucine and is involved in the methionine chain elongation cycle for glucosinolate formation [33], was identified as a JR gene and involved in oxidative response [32]. The induced carbonic anhydrase was previously reported to be elevated during pathogen attack and consequently high ROS activity [34], and to act as an antioxidant and active player in plant disease resistance [35]. The induced oxidoreductase acyl-[acyl-carrier-protein] desaturase can have an antioxidant effect as well, because it can reduce $\mathrm{O}^{-}$to two molecules of water [36]. The overexpression of this enzyme in tobacco under chilling stress significantly reduced ROS levels in the plant tissue and allowed elevated activity of antioxidant enzymes [36]. A phosphoserine phosphatase that is involved in amino acid production [37] can have oxidative effect as well since amino acids are known as antioxidants in plants [38] and phosphoserine phosphatase was reported previously to involve in stress tolerance [37]. Aspartate aminotransferase as well can be involved in antioxidant defense by the production of glutamate. It was previously reported that the glutamate metabolic flux was dominant in oxidative defense under water stress [39]. The acyl-CoA-binding protein was found to induce plant tolerance to various stresses including oxidative stress [40,41].

Additional genes can be involved in the antioxidant defense due to their activity in metabolic pathways. An overexpression of dihydroflavonol-4-reductase, which is involved in anticyonine production, led to cell-death resistance in rice due to reduction of hydrogen peroxide concentration [42]. Moreover the elevated NADPH levels observed in a rice mutant [42] can be supplied to the glutathione redox cycle for protection against ROS [43]. Surprisingly, important ROS scavengers such as superoxide dismutases (SODs), catalases (CATs), peroxidases and ascorbate peroxidase (APX), were not affected on the transcriptome level in the studied regions of the growth zone. Expression analysis for APX by Real-Time 
PCR supported this result (Figure 3). This is also in accord with a previous study from our lab which identified highest activity level of APX at the basal $15 \mathrm{~mm}$ region from the leaf base [7].

In light of the high expression of genes involved in antioxidant defense under salinity, it is suggested that they are the cause of the low ROS levels in the elongation region under salinity, and consequently the reduced cellwall loosening. The plants have a very effective antioxidant system that facilitates maintenance of a tight ROS balance in the cell [2], and easily adapts to changes in ROS under abiotic stresses [2]. Indeed, in the distal part of the growth zone, only two genes involved in antioxidant activity were identified, and one of them was reduced under stress. This could result from the well documented reduction in photosynthetic activity under salinity [8]. Thereby, the plant adaptive strategy to prevent excess of ROS under stress condition by a massive expression of ROS scavengers, results in a negative effect on growth, i.e., growth restriction. From a plant survival, and thereby evolutionary perspective, growth restriction should be less damaging than the direct tissue damage which could occur by the stress-induced elevation of ROS.

In addition to genes belonging to the antioxidant defense system, various genes that can be classified into energy, photosynthetic and structural groups were affected as well by salinity. The elevation of these genes reflects the earlier maturation of the salt-stressed leaf tissues compared to the control; represent involvement in protection against the $\mathrm{NaCl}$ damages by an antioxidative defense; or participation in cell growth restriction mechanisms. For instance, reduced levels of ACC oxidase in salt-stressed plants in the 30-50 mm region that points to higher ethylene production [44], likely correspond to the difference in tissue age between the two treatments. I.e., the tissue found at the distal region of growth zone in salt-stressed plants is older than in the control treatment. This correlates with the observed elevation under salinity of the hydroxyprolinerich glycoprotein (HRGP), that is a component of the cellwall produced in maize in an ethylene-dependent process, in the same region [45]. This elevation suggests an increase in cell-wall rigidity since HRGPs contain short rigid blocks of contiguous $\mathrm{O}$-glycosylated hydroxyproline residues that involve in intermolecular cross-linking and cell-wall formation [46]. The dirigent protein pDIR9 was elevated as well under stress. Dirigent proteins are involved in lignin biosynthesis, act as physical barriers, have a strengthening role and repair damaged cell-walls [47]. Consequently they can increase rigidity under stress due to increased lignification and reduced cell-wall loosening. Effect of $\mathrm{NaCl}$ on these three proteins therefore points to earlier maturation of cells under salt stress and higher rigidity of the cell-wall under stress. The resulted higher rigidity under salinity will also reduce cell-wall loosening and hence the ability for cell enlargement. Elevation of these proteins under salinity in cells of the 30-50 $\mathrm{mm}$ region therefore correlates with the heightened growth sensitivity to salinity of this region compared to the younger region found $15-30 \mathrm{~mm}$ from the base (Tables 1 and 2). Earlier cessation of growth under salinity was demonstrated for the leaves studied in the present project (Figure 1) as well as in several other studies with monocot leaves $[4,9,10]$.

Some of the genes identified by the $\mathrm{SSH}$, such as the elongation factor EF1A or cyclophyllin, are known to have chaperones activity $[48,49]$. Salinity is known to promote protein dysfunction and reduce protein stability, and chaperones and heat-shock proteins are considered to involve in salt resistance by sustaining protein stability and function and prevention of protein aggregation [50]. In the young cells from the $15-30 \mathrm{~mm}$ region, three different Hsp70 were induced (Table 3), while in the $30-50 \mathrm{~mm}$ zone no genes that their products have chaperone functions were isolated and moreover, two isolated EFs were down-regulated pointing at lower protection against stress. Moreover, it was previously suggested that Hsp70 is involved in protein trafficking to peroxisomes [51] and consequently can affect peroxisome antioxidant activity. Again, these results correlate with the higher sensitivity to salinity of the older cells from the $30-50 \mathrm{~mm}$ region compared to the younger tissue from the $15-30 \mathrm{~mm}$ region. Overexpression of DnaK1 (a member of the Hsp70 group) in tobacco was demonstrated before to induce salt tolerance [52]. Taken together, these results demonstrate more protection against the stress in the $15-30 \mathrm{~mm}$ region compared to the $30-50 \mathrm{~mm}$ region, correlating to the difference in the extent of stress-induced growth reduction between these two regions.

Under salinity, increased energy demand for maintenance processes such as compartmentation and osmotic adjustment, coupled with reduced energy production via effects on the photosynthetic apparatus, might reduce energy availability in the plant. Sensitivity of growing cells to salinity might therefore be affected by localized energy-generating biochemical processes and genes involved in energy supply. As an adaptation mechanism, inorganic pyrophosphatase $\left(\mathrm{H}^{+}\right.$-PPase) activity can be induced. $\mathrm{H}^{+}$PPase, can replace glycolytic ATP consuming enzyme reactions partially by reactions which utilize inorganic pyrophosphate (PPi) as an alternative energy source [53]. Induction of $\mathrm{H}^{+}$-PPase by $\mathrm{NaCl}$ increased with distance from the leaf base, i.e., cell age, along the growth zone. The smallest change was observed at the region of highest growth (15-30 mm from the leaf base). The higher expression of PPi at the distal part of the growth zone, where the cells are older, may suggest that the demand for alternative energy increases with prolonged exposure to the stress. At the same time vacuolar $\mathrm{H}^{+}$-PPase was isolated at the younger region. It can supply energy similar 
to PPi and can supplement energy demands at the region of highest growth. At 15-30 mm from leaf base (the center of the growing zone) additional genes involved in energy metabolism were induced by salinity, and overall this zone was affected by salinity more than the older zone, marking it as the primary affected cell developmental stage.

\section{Conclusions}

The results observed in this study suggest that growth restriction under salt stress is induced by at least two processes. First, induced expression of genes encoded to products that acts as ROS scavengers results in reduction of ROS levels in the growing cells. This is supported by previous observations in monocot leaves $[7,9]$. The resulted reduction in ROS is involved in growth restriction under salt stress by reducing cell-wall loosening [9]. Second, induction of genes that enhance cell-wall rigidity reduces the capacity for cell expansion. Thereby, in the growth zone the cell-wall under stress may be more rigid and less attacked by ROS, resulting in cell growth restriction. Previously cell-wall rigidity was shown to increase by salinity in tips of maize roots [54] and under water deficit in growing leaves of maize [55]. Reduced sensitivity to salinity of younger cells from the center of the elongation zone, compared to older cells from more distal locations of the elongation zone was demonstrated for numerous grass leaves including maize (Figure 1) $[7,17]$. The differential transcriptomic results for the cells of the two developmental stages suggest that the higher growth sensitivity to salinity of the older cells might involve lower protein protection against the stress and higher cell-wall rigidity in the older cells. The detailed characterization of stress-inducible genes obtained in the current research increases our understanding of molecular mechanisms of salt stress effects in higher plants, and is also useful for directing programs geared at improving salinity tolerancespecifically towards optimization of the antioxidant response and cell-wall hardening processes in the growing cells of the leaf.

\section{Methods}

\section{Plant material and growing conditions}

Seeds of maize (Zea mays cv G.S. 46, Galilee Seeds, Haifa, Israel) were soaked in aerated solution $(2 \mathrm{mM} \mathrm{KCl}$ and $1 \mathrm{mM} \mathrm{CaCl}_{2}$ ) for $6 \mathrm{~h}$ and than sown on moist vermiculite in plastic boxes. Plants were cultivated as previously described [4]. In short, the vermiculite was pretreated with $15 \mathrm{mM} \mathrm{Ca}$ $\left(\mathrm{NO}_{3}\right)_{2}$ for $2 \mathrm{~h}$, rinsed twice and later soaked in 0.1 concentration-modified Hoagland solution [19] for $2 \mathrm{~h}$ prior to sowing. The boxes were covered and kept in the dark at $25^{\circ} \mathrm{C}$ until $\mathrm{d} 4$ when illumination started $\left(400 \mu \mathrm{E} \mathrm{s}^{-1} \mathrm{~m}^{-2}\right.$, 16 -h photoperiod, relative humidity of $60 \%$ and $80 \%$ during the day and night, respectively). On $\mathrm{d} 7$, plants with similar lengths of leaf 1 and $2(80 \pm 10 \mathrm{~mm})$ were selected and transferred to aerated one-quarter-strength modified Hoagland solution [56]. Micronutrients were supplied as in one-half Hoagland concentration, except that iron was added as $50 \mu \mathrm{M}$ Fe-EDTA and $20 \mu \mathrm{M} \mathrm{Fe}\left(\mathrm{NH}_{4} \mathrm{SO}_{4}\right)_{2}$ and $\mathrm{Na}$ level was elevated to $1 \mathrm{mM}$. Solution $\mathrm{pH}$ was adjusted to 5.7 with addition of $\mathrm{KOH}$. Growth chamber conditions remained as described above. Salinization began with the transfer to hydroponics on day 7. At this time leaf 3 was not yet visible and leaf 4 was shorter than $10 \mathrm{~mm} . \mathrm{NaCl}$ concentration in the growing medium was elevated in three daily steps (to 20,50, and finally $80 \mathrm{mM}$ ) [4]. Control plants remained at a total concentration of sodium and chloride of $1 \mathrm{mM}$ each.

\section{Plant growth analysis}

\section{Shoot and leaf development}

Daily leaf length measurements were used for evaluation of shoot growth, and calculations of leaf elongation rates. Leaf length was measured daily with a ruler to the nearest $0.5 \mathrm{~mm}$ from the base of the plant to the tip of the leaf [57]. Leaf number 4, of 14- day old plants was selected for the experimental system in this study since the plastochron was lengthened under salinity from leaf 5 on and leaf 4 of the control and salt-stressed plants emerge above the whorl of encircling older leaf sheaths on the same day. Selection of this leaf therefore prevents complications arising from interpretation of experimental results from leaves which differ in developmental stage [4]. Furthermore, on this day, this leaf was at the rapid phase of elongation and thereby contained cells at all stages of development: from dividing cells in the basal meristem located near the point of leaf attachment to the node, to growing and mature cells at more distal locations.

For all measurements conducted in the study the plant tissue was sampled for analyses on day 7 after the beginning of salinization, when the plants were 14-days-old.

\section{Biomass determination}

For biomass determination, growing leaf segments located at the region of highest growth (15-30 mm from the leaf base) and the distal part of growth zone (located 30-50 $\mathrm{mm}$ from leaf base), which are equivalent to the locations used for the $\mathrm{SSH}$ analyses were excised from the leaf. The age of cells in the center of the $15-30 \mathrm{~mm}$ segment from the control and salt treated plants was $30.6 \mathrm{~h}$ and $48.6 \mathrm{~h}$, respectively, and $39.6 \mathrm{~h}$ and $61.2 \mathrm{~h}$ respectively in the $30-50 \mathrm{~mm}$ segment (Neves-Piestun and Bernstein, unpublished). Four replicated leaves from different plants were aligned and cut together, so that 4 cut segments were combined into samples by position. Fresh biomass was recorded immediately following excision from the plant. Dry biomass was measured after drying at $60^{\circ} \mathrm{C}$ for $48 \mathrm{~h}$ and cooling for $24 \mathrm{~h}$ in a desiccation chamber. Weights were measured with a Precisa 40SM-200A balance 
(Zurich, Switzerland) to the nearest $10 \mu \mathrm{g}$. The fresh and dry weights were used for calculations of \% dry weight, $\%$ DW, of the tissue.

\section{Mineral analysis of the plant tissue}

Tissue located $15-30 \mathrm{~mm}$ and $30-50 \mathrm{~mm}$ from the leaf base of leaf 4 was sampled for mineral analyses as well. Contents of $\mathrm{Ca}$, as well as the salinity sources $(\mathrm{Na}, \mathrm{Cl})$ in the leaf tissue were determined as previously described [19]. Segments from 5 replicated leaves from different plants were combined by position for each sample. Fresh and dry weights were recorded with a Precisa 40SM-200A balance (Zurich, Switzerland) to the nearest $0.00001 \mathrm{~g}$, and percentage of water in the tissue was calculated. In short, for the analysis of $\mathrm{Ca}$, the dried plant samples were digested with $\mathrm{HNO}_{3}$ and $\mathrm{HClO}_{4}$ (65\% and 60\%, respectively). The extract was analyzed for $\mathrm{Ca}$, by inductively coupled plasma atomic emission spectrometry (ICP-AES), (Spectro, Kleve, Germany). For the analysis of $\mathrm{Na}$ and $\mathrm{Cl}$ the dry tissue was extracted with a dilute acid solution containing $0.64 \% \mathrm{HNO}_{3}$ and $10 \% \mathrm{CH}_{3} \mathrm{COOH}$. Samples were analyzed for chloride by potentiometric tritation (Buchler chloridmeter, New Jersey, USA) and for sodium by flame photometry (Instrumentation Laboratory, USA).

\section{RNA extraction, CDNA production, PCR, cloning of PCR products, subtraction library}

For the subtraction libraries, the region of highest growth (15-30 mm from leaf base) and the distal part of growth zone (located 30-50 mm from leaf base) were selected. For quantitative Real-Time PCR analyses, the growing zone was sectioned into 4 regions: $20-25,35-40,50-55$, 60-65 mm from leaf base. RNA was extracted by Trireagent (Sigma-Aldrich $\mathrm{Co}$ ) according to the manufacturer's instructions. For removal of genomic DNA from RNA preparations DNAse (Fermentas Inc, Maryland, USA) treatment was produced accordingly to the manufacturer's instructions. cDNA was produced by verso cDNA kit (Thermo Fisher Scientific Inc., ABgene House, Surrey, UK) accordingly to the manufacturer's instructions. A PCR-select cDNA subtraction kit (Clontech
Laboratories Inc., Mountain View, USA) was used for the generation of the subtraction library, and screening of the subtraction library was performed with a PCR-select differential screening kit (Clontech Laboratories Inc., Mountain View, USA). The forward subtraction used tester cDNA obtained from mRNA of salt-treated tissues and driver cDNA from control treatment. In the reverse subtraction, the tester cDNA was obtained from mRNA of control treatment and driver cDNA from salt-treated tissues. Dot-blot analysis was performed with a PCR-select differential screening kit (Clontech Laboratories Inc., Mountain View, USA). Around 90 clones from these libraries were sequenced and gene identities were determined by sequence comparison to the nonredundant GenBank database using BLASTn, using default parameters. In instances where an unannotated match was obtained, BLASTp (www.ncbi.nlm.nih.gov) searchers were conducted and sequence homology information was used to assign putative identities.

\section{Quantative real-time -PCR}

Real-Time PCR was performed with Absolute Blue QPCR Sybr Green ROX mix (Thermo Fisher Scientific Inc., ABgene House, Surrey, UK) at Mx3000P ${ }^{\circledR}$ QPCR System (Stratagene, La Jolla, CA, USA). All reactions were performed with 4-5 independent biological repeats, with triplicate testing for each replicate. The relative abundance of transcripts was normalized with actin. Data were analyzed using the MxPro-Mx3000P v.4 and relative quantity (RQ) was calculated from Real-Time PCR data by $2-\Delta \Delta C T$. Primer are listed in Table 4. Statistical analysis was performed in JMP 5.0.1 (SAS Institute Inc, Raleigh, NC, USA).

\section{Determination of content of reactive oxygen species Hydrogen peroxide $\left(\mathrm{H}_{2} \mathrm{O}_{2}\right)$ determination}

$\mathrm{H}_{2} \mathrm{O}_{2}$ level in the tissue was analyzed along the developmental gradients of leaf 4 at day 14 . Leaves were attached to a glass plate and tissue disks, $6 \mathrm{~mm}$ in diameter, were sampled from several regions: $10-20 \mathrm{~mm}, 20-30 \mathrm{~mm}$, 30-40, 40-50, 60-70 $\mathrm{mm}$ from leaf base. The disks were washed with double distilled water and immediately

Table 4 List of primers used for the Real-Time PCR analysis

\begin{tabular}{|c|c|c|c|}
\hline Gene name & Gl & Forward primer $5^{\prime}-3^{\prime}$ & Reverse primer $5^{\prime}-3^{\prime}$ \\
\hline Actin & 99030435 & TGCTGAGCGAGAAATTGTCAGGG & TTCCATGCCAATGAAGGATGGCT \\
\hline$A P X$ & 600115 & ATCGCCGAGAAGAATTGCG & GGTTCTTCATGGTGCCGAA \\
\hline$P P i$ & 195610705 & GAGCTCTCGTTGGCCTGATTT & ACGAAGAAGCATGGTCACAGC \\
\hline$V-P P i$ & 238011099 & GTGTTGCAATTGGTCTGTGG & CTGCAAGAATCTGCAACGTC \\
\hline pDIR9 & 226498795 & CCACTTCTTCTTCCACGACAC & TCCATCACGTTCACCATCC \\
\hline PPlase & 226500875 & AGCTITGCACCAAGGTTCTG & TCAGGATCGATTTCCAGTGC \\
\hline$I C O A D H$ & 195642911 & ATGTCGTCAGCATGAAGTGC & CGTAAACAACCAGTGTCTGAGC \\
\hline
\end{tabular}

Inorganic pyrophosphate (PPi), vacuolar inorganic pyrophosphate (V-PPi), ascorbate peroxidase (APX), isovaleryl-CoA dehydrogenase (ICoA DH), peptidyl-prolyl isomerase (PPlase). 
analyzed for $\mathrm{H}_{2} \mathrm{O}_{2}$. The hydrogen peroxide levels were determined using 2,7- dihydrodichlorofluorescein diacetate $\left(\mathrm{H}_{2} \mathrm{DCF}-\mathrm{DA}\right)$ [58]. Solution of $25 \mathrm{mM}$ was prepared in methanol and kept at $-20^{\circ} \mathrm{C}$ pending use. Discs were transferred to small wells of ELISA plates containing $200 \mu \mathrm{l}$ of fresh MES buffer (50 mM; pH 6.2) and $10 \mu \mathrm{M}$ of $\mathrm{H}_{2}$ DCF-DA. Following incubation for $30 \mathrm{~min}$ at room temperature, fluorescence was measured with a microplate fluorescence reader FL600 (Bio-Tek, Vermont, USA), using $485 \mathrm{Ex}$ and $530 \mathrm{Em}$ filters [58]. Results expressed in fluorescent units and each data point represent an average $\pm \operatorname{SE}(n=5)$.

\section{Superoxide determination}

A $70 \mathrm{~mm}$ segment was sectioned from the base of leaf 4 of 14-day-old plants for superoxide determination. Immediately following excision from the plant, the tissue was gently washed for $30 \mathrm{sec}$ in DDW and subjected to staining for superoxides. Superoxides accumulation in tissue was determined with nitrotetrazolium blue (NBT, SigmaAldrich Co, St. Louis, USA) [16], which reacts with $\mathrm{O}_{2}^{--}$, producing a blue formazan precipitate. The segment was gently vacuum infiltrated $(2 \mathrm{~min}$ ) with $0.01 \%$ NBT solution and incubated in the dark in the same solution for $2 \mathrm{~h}$ at $30^{\circ} \mathrm{C}$ under very slow shaking. To determine that this staining was attributed to the formation of $\mathrm{O}_{2}^{--}, \mathrm{MnCl}_{2}$ $(10 \mathrm{mM})$, a highly effective $\mathrm{O}_{2}^{--}$dismutating catalyst agent [16], was added together with NBT as a control. After staining, the chlorophyll was removed from the tissue by boiling the segments in 9:1 solution of ethanol and glycerin for $10 \mathrm{~min}$. Color density was checked with Image $1.42 \mathrm{q}$ (NIH, USA, http://rsbweb.nih.gov/ij/). Results are expressed as color density and each data point represent an average \pm SE $(n=4)$.

\section{Statistical analysis}

Results are expressed as means \pm standard errors (SE). Statistical analysis was performed using JMP 5 software (SAS Institute Inc., 2002, Cary, NC, USA). Data were subjected to one-way ANOVA analysis and Tukey honestly significant difference for comparison of means.

\section{Competing interests}

The authors declare that they have no competing interests.

\section{Authors' contributions}

MK performed the SSH analysis, RT PCR analysis, ROS analysis and drafted the manuscript. NB conceived of the study, performed the growth kinematics analysis, mineral ion analyses and revised the text. Both authors read and approved the final manuscript.

\section{Acknowledgements}

Dr. Mariela Faure-Mlinsky was involved in early stages of the SSH library construction.

Received: 28 June 2012 Accepted: 18 December 2012

Published: 16 January 2013

\section{References}

1. Cramer GR: Response of abscisic acid mutants of Arabidopsis to salinity. Func Plant Biol 2002, 29:561-567.

2. Munns R, Tester M: Mechanisms of salinity tolerance. Ann Rev Plant Biol 2008, 59:651-681.

3. Lazof DB, Bernstein N: The NaCl-induced inhibition of shoot growth: the case for disturbed nutrition with special consideration of calcium nutrition. Adv Bot Res 1998, 29:113-189.

4. Neves-Piestun BG, Bernstein N: Salinity-induced inhibition of leaf elongation in maize is not mediated by changes in cell wall acidification capacity. Plant Physiol 2001, 125:1419-1428.

5. Hu YC, Fricke W, Schmidhalter U: Salinity and the growth of nonhalophytic grass leaves: the role of mineral nutrient distribution. Func Plant Biol 2005, 32:973-985.

6. Hasegawa PM, Bressan RA, Zhu JK, Bohnert HJ: Plant cellular and molecular responses to high salinity. Annu Rev Plant Physiol Plant Mol Biol 2000, 51:463-499.

7. Bernstein N, Shoresh M, Xu Y, Huang BR: Involvement of the plant antioxidative response in the differential growth sensitivity to salinity of leaves vs roots during cell development. Free Rad Biol Med 2010, 49:1161-1171.

8. Munns R, James RA, Läuchli A: Approaches to increasing the salt tolerance of wheat and other cereals. J Exp Bot 2006, 57:1025-1043.

9. Rodríguez AA, Cordoba AR, Ortega L, Taleisnik E: Decreased reactive oxygen species concentration in the elongation zone contributes to the reduction in maize leaf growth under salinity. J Exp Bot 2004, 55:1383-1390.

10. Hu YC, Burucs Z, von Tucher S, Schmidhalter U: Short-term effects of drought and salinity on mineral nutrient distribution along growing leaves of maize seedlings. Environm Exp Bot 2007, 60:268-275.

11. Flowers TJ: Improving crop salt tolerance. J Exp Bot 2004, 55:307-319.

12. Gong Z, Koiwa H, Cushman MA, Ray A, Bufford D, Kore-eda S, Matsumoto TK, Zhu J, Cushman JC, Bressan RA, Hasegawa PM: Genes that are uniquely stress regulated in salt overly sensitive (sos) mutants. Plant Physiol, 126:363-375.

13. Wang H, Miyazaki S, Kawai K, Deyholos M, Galbraith DW, Bohnert HJ: Temporal progression of gene expression responses to salt shock in maize roots. Plant Mol Biol 2003, 52:873-891.

14. Ouyang B, Yang T, Li H, Zhang L, Zhang Y, Zhang J, Fei Z, Ye Z: Identification of early salt stress response genes in tomato root by suppression subtractive hybridization and microarray analysis. J Exp Bot 2007, 58:507-520.

15. Qing DJ, Lu HF, Li N, Dong HT, Dong DF, Li YZ: Comparative profiles of gene expression in leaves and roots of maize seedlings under conditions of salt stress and the removal of salt stress. Plant Cell Physiol 2009, 50:889-903.

16. Hernández JA, Ferrer MA, Jimenez A, Ros Barcelo A, Sevilla F: Antioxidant systems and $\mathrm{O}_{2}^{-} / \mathrm{H}_{2} \mathrm{O}_{2}$ production in the apoplast of pea leaves: its relation with saltinduced necrotic lesions in minor veins. Plant Physiol 2001, 127:817-831.

17. Shoresh M, Spivak M, Bernstein N: Involvement of calcium-mediated effects on ROS metabolism in the regulation of growth improvement under salinity. Free Radic Biol Med 2011, 51:1221-1234.

18. Schnyder H, Nelson CJ: Diurnal growth of tall fescue leaf blades. I. Spatial distribution of growth, deposition of water, and assimilate import in the elongation zone. Plant Physiol 1988, 86:1070-1076.

19. Neves-Piestun BG, Bernstein N: Salinity-induced changes in the nutritional status of expanding cells may impact leaf growth inhibition in maize. Funct Plant Biol 2005, 32:141-152.

20. Rodríguez AA, Grunberg KA, Taleisnik EL: Reactive oxygen species in the elongation zone of maize leaves are necessary for leaf extension. Plant Physiol 2002, 129:1627-1632.

21. Foreman J, Demidchik V, Bothwell JHF, Mylona P, Miedema H, Torres MA, Linstead P, Costa S, Brownlee C, Jones JDG, et al: Reactive oxygen species produced by NADPH oxidase regulate plant cell growth. Nature 2003, 422:442-446.

22. Schopfer $P$, Liszkay A: Plasma membrane-generated reactive oxygen intermediates and their role in cell growth of plants. Biofactors 2006, 28:73-81.

23. Dat J, Vandenabeele S, Vranova E, Van Montagu M, Inze D, Van Breusegen F: Dual action of the active oxygen species during plant stress responses. Cell Mol Life Sci 2000, 57:779-995. 
24. Hortensteiner S: Chlorophyll degradation during senescence. Ann Rev Plant Biol 2006, 57:55-77.

25. Chinnusamy V, Jagendorf A, Zhu JK: Understanding and improving salt tolerance in plants. Crop Sci 2005, 45:437-448

26. Millar AH, Whelan J, Soole KL, Day DA: Organization and regulation of mitochondrial respiration in plants. Annu Rev Plant Biol 2011, 62:79-104.

27. Lehmann M, Schwarzlander M, Obata T, Sirikantaramas A, Burow M, Olsen C, Tohge T, Fricker M, Moller B, Fernie A, et al: The metabolic response of Arabidopsis roots to oxidative stress is distinct from that of heterotrophic cells in culture and highlights a complex relationship between the levels of transcripts, metabolites, and flux. Mol Plant 2009, 2:390-406.

28. Buchanan-Wollaston V, Page T, Harrison E, Breeze E, Lim PO, Nam HG, Lin JF, Wu SH, Swidzinski J, Ishizaki K, Leaver CJ: Comparative transcriptome analysis reveals significant differences in gene expression and signaling pathways between developmental and dark/starvation-induced senescence in Arabidopsis. Plant J 2005, 42:567-585

29. Araújo WL, Ishizaki K, Nunes-Nesi A, Larson TR, Tohge T, Krahnert I, Witt S, Obata T, Schauer N, Graham IA, et al: Identification of the 2hydroxyglutarate and isovaleryl-coa dehydrogenases as alternative electron donors linking lysine catabolism to the electron transport chain of arabidopsis mitochondria. Plant Cell 2010, 22:1549-1563.

30. Izawa S, Maeda K, Miki T, Mano J, Inoue Y, Kimura A: Importance of glucose-6-phosphate dehydrogenase in the adaptive response to hydrogen peroxide in Saccharomyces cerevisiae. Biochem J 1998, 330:811-817.

31. Noctor G, Foyer $\mathrm{CH}$ : Ascorbate and glutathione: keeping active oxygen under control. Ann Rev Plant Physiol Plant Mol Biol 1998, 49:249-279.

32. Sasaki-Sekimoto Y, Taki N, Obayashi T, Aono M, Matsumoto F, Sakurai N, Suzuki H, Hirai MY, Noji M, Saito K, et al: Coordinated activation of metabolic pathways for antioxidants and defence compounds by jasmonates and their roles in stress tolerance in Arabidopsis. Plant $J$ 2005, 44:653-668.

33. Knill T, Reichelt M, Paetz C, Gershenzon J, Binder S: Arabidopsis thaliana encodes a bacterial-type heterodimeric isopropylmalate isomerase involved in both Leu biosynthesis and the Met chain elongation pathway of glucosinolate formation. Plant Mol Biol 2009, 71:227-239.

34. Collins RM, Afzal M, Ward DA, Prescott MC, Sait SM, Rees HH, Tomsett AB: Differential proteomic analysis of Arabidopsis thaliana genotypes exhibiting resistance or susceptibility to the insect herbivore, Plutella xylostella. PLoS One 2010, 5:e10103.

35. Slaymaker DH, Navarre DA, Clark D, del Pozo O, Martin GB, Klessig DF: The tobacco salicylic acid-binding protein 3 (SABP3) is the chloroplast carbonic anhydrase, which exhibits antioxidant activity and plays a role in the hypersensitive defense response. Proc Natl Acad Sci USA 2002, 99:11640-11645.

36. Popov VN, Kipaikina NV, Astakhova NV, Trunova TI: Specific features of oxidative stress in the chilled tobacco plants following transformation with the desC gene for acyl-lipid $\Delta 9$-desaturase from Synechococcus vulcanus. Rus J Plant Physiol 2006, 53:469-473.

37. Ho CL, Saito K: Molecular biology of the plastidic phosphorylated serine biosynthetic pathway in Arabidopsis thaliana. Amino Acids 2001, 20:243-259.

38. Bilski P, Li MY, Ehrenshaft M, Daub ME, Chignell CF: Vitamin B6 (pyridoxine) and its derivatives are efficient singlet oxygen quenchers and potential fungal antioxidants. Photochem Photobiol 2000, 71:129-134.

39. Liu C, Zhao L, Yu G: The dominant glutamic acid metabolic flux to produce $\gamma$-amino butyric acid over proline in Nicotiana tabacum leaves under water stress relates to its significant role in antioxidant activity. J Integr Plant Biol 2011, 53:608-618.

40. Gao W, Li HY, Xiao S, Chye ML: Acyl-CoA-binding protein 2 binds lysophospholipase 2 and lysoPC to promote tolerance to cadmiuminduced oxidative stress in transgenic Arabidopsis. Plant J 2010, 62:989-1003.

41. Meng W, Su YCF, Saunders RMK, Chye ML: The rice acyl-CoA-binding protein gene family: phylogeny, expression and functional analysis. New Phytol 2011, 189:1170-1184.

42. Hayashi M, Takahashi H, Tamura K, Huang JR, Yu LH, Kawai-Yamada M, Tezuka T, Uchimiya H: Enhanced dihydroflavonol-4-reductase activity and NAD homeostasis leading to cell death tolerance in transgenic rice. Proc Natl Acad Sci USA 2005, 102:7020-7025.
43. Dorval J, Hontela A: Role of glutathione redox cycle and catalase in defense against oxidative stress induced by endosulfan in adrenocortical cells of rainbow trout (Oncorhynchus mykiss). Toxicol Appl Pharmocol 2003, 192:191-200.

44. Vriezen WH, Hulzink R, Mariani C, Voesenek LACJ: 1-aminocyclopropane-1carboxylate oxidase activity limits ethylene biosynthesis in Rumex palustris during submergence. Plant Physiol 1999, 121:189-195.

45. Josè-Estanyol M, Puigdomènech $P$ : Developmental and hormonal regulation of genes coding for proline-rich proteins in female inflorescences and kernels of maize. Plant Physiol 1998, 116:485-494

46. Cannon MC, Terneus K, Hall Q, Tan L, Wang Y, Wegenhart BL, Chen L, Lamport DTA, Chen Y, Kieliszewski MJ: Self-assembly of the plant cell wall requires an extensin scaffold. Proc Natl Acad Sci USA 2008, 105:2226-2231.

47. Ralph S, Park JY, Bohlmann J, Shawn D: Dirigent proteins in conifer defense: gene discovery, phylogeny and differential wound and insectinduced expression of a family of DIR and DIR-like genes in spruce (Picea spp.). Plant Mol Biol 2006, 60:21-40.

48. Caldas TD, El Yaagoubi A, Richarme G: Chaperone properties of bacterial elongation factor EF-Tu. J Biol Chem 1998, 273:11478-11482.

49. Freskgard PO, Bergenhem N, Jonsson BH, Svensson M, Carlsson U: Isomerase and chaperone activity of prolyl isomerase in the folding of carbonic anhydrase. Science 1992, 258:466-468.

50. Wang W, Vinocur B, Altman A: Plant responses to drought, salinity and extreme temperatures: towards genetic engineering for stress tolerance. Planta 2003, 218:1-14.

51. Pratt WB, Krishna P, Olsen LJ: Hsp90-binding immunophilins in plants: the protein movers. Trends Plant Sci 2001, 6:54-58.

52. Sugino M, Hibino T, Tanaka Y, Nii N, Takabe T: Overexpression of DnaK from a halotolerant cyanobacterium Aphanothece halophytice acquires resistance to salt stress in transgenic tobacco plants. Plant Sci 1999, $146: 81-88$.

53. Drozdowicz YM, Rea PA: Vacuolar $\left.\mathrm{H}^{+}\right)$pyrophosphatases: from the evolutionary backwaters into the mainstream. Trends Plant Sci 2001, 6:206-211.

54. Neumann PM, Azaizeh H, Leon D: Hardening of roots cell walls: a growth inhibitory response to salinity stress. Plant Cell Env 1994, 17:303-309.

55. Chazen O, Neumann PM: Hydraulic signals from the roots and rapid cellwall hardening in growing maize (Zea mays 1.) leaves are primary responses to polyethylene glycol-induced water deficits. Plant Physiol 1994, 104:1385-1392.

56. Bernstein N, Silk WK, Läuchli A: Growth and development of sorghum leaves under conditions of $\mathrm{NaCl}$ stress: possible role of some mineral elements in growth inhibition. Planta 1995, 196:699-705.

57. Bernstein N, Silk WK, Läuchli A: Growth and development of sorghum leaves under conditions of $\mathrm{NaCl}$ stress: spatial and temporal aspects of leaf growth inhibition. Planta 1993, 191:433-439.

58. Rosenwasser $\mathrm{S}$, Mayak S, Friedman $\mathrm{H}$ : Increase in reactive oxygen species (ROS) and in senescence-associated gene transcript (SAG) levels during dark-induced senescence of Pelargorium cuttings and the effect of gibberellic acid. Plant Sci 2006, 170:873-879.

doi:10.1186/1471-2164-14-24

Cite this article as: Kravchik and Bernstein: Effects of salinity on the transcriptome of growing maize leaf cells point at cell-age specificity in the involvement of the antioxidative response in cell growth restriction. BMC Genomics 2013 14:24. 